\title{
Agricultural Management Greatly Affects the Beneficial Entomofauna of the Olive Groves
}

\author{
R González Ruiz ${ }^{1 *}$ and J A Gómez Guzmán² \\ Department of Animal Biology, Jaen University, Spain \\ *Corresponding author: R González Ruiz, Department of Animal Biology, Jaen University, Spain \\ To Cite This Article: R González Ruiz, J A Gómez Guzmán. Agricultural Management Greatly Affects the Beneficial Entomofauna of the Olive \\ Groves. Am J Biomed Sci \& Res. 2019 - 1(3). AJBSR.MS.ID.000530. DOI: 10.34297/AJBSR.2019.01.000530
}

Received: January 09, 2019 | Published: February 22, 2019

\begin{abstract}
In the course of the last decades there has been a remarkable evolution in the agricultural practices carried out in olive growing, from a conventional management (CM), based on the systematic application of pesticides and lacking vegetal cover, to the Integrated pest Management (IPM), in which the application of pesticides is limited, being applied according to more rational criteria. In addition, an herbaceous vegetation cover is maintained in the olive grove, in order to limit soil erosion. Although they are of a minority nature, a lower proportion of olive groves are subject to Ecological Management (EM), in which pesticides are eliminated completely and the herbaceous vegetation cover is maintained, being only subject to scarce tillage operations. Here, the control of pests is exercised exclusively by beneficial fauna.
\end{abstract}

The main objective of this study is to determine the impact of each of these agricultural management methods on beneficial entomofauna associated with the olive tree and characterize them according to the presence and abundance of a series of preselected species, characteristics of this agroecosystem.

The study has been carried out by means of entomological samples in olive groves of the province of Jaén (south of Spain) corresponding to the three managements indicated above, during the spring of 2017. The results have allowed to select a total of 18 bioindicator species (11 predators and 7 parasitoids), all of them present in the Ecological, where they also presented the highest population densities. The lowest diversity and abundance corresponded to the conventional management, while the Integrated Management presented intermediate values with respect to the Conventional and Ecological management. The role of agricultural practices differential between these managements, are discussed.

Keywords

Olive growing; Conventional management; Integrated pest management (IPM); Ecological management; Beneficial fauna; Predators; Parasitoids; Olive pests; Sustainable olive groves; Chrysopidae; Anthocoridae; Aeolothripidae; Raphidiidae; Syrphidae; Eulophidae; Encyrtidae; Braconidae; Ichneumonidae; Encyrtidae

\section{Introduction}

In the Mediterranean countries there is a growing interest in developing more effective and sustainable strategies and tactics to preserve crops from the action of the phytophagous [1]. As in other perennial crops, the current conception of olive management considers as an essential element the stimulation and conservation of biodiversity, which implies, among other factors, the implantation of herbaceous vegetation cover. With this measure, besides limiting the erodibility [2], it is intended to enhance the interactions: phytophagous-entomophagous, and therefore optimize the natural control mechanisms [3-9].

With this objective, in recent years there has been a shift from a traditional, or conventional, situation based on the widespread and indiscriminate use of pesticides, of crops free of plant cover, to Integrated Pest Management [10]. IPM emerged as a response to the need to minimize the harmful effects generated by the indiscriminate use of pesticides, which combines different management strategies and practices for healthy crops, minimizing the impact of pesticides [11]. Regarding conventional management, IPM involves the elimination of unnecessary pesticide applications, being used at the smallest effective, in bringing a pest organism to acceptable limits with as little ecological disruption as possible [12]. This therefore requires an accurate knowledge of the population variations of the pests.

However, the effectiveness of natural enemies in the natural control of pests is greatly affected by various factors, such as the landscape configuration around the cultivation area [13], by 
the practices applied by the farmers. Therefore, a higher level is represented by the Ecological management, which corresponds to the maximum exponent, and must provide a maximum efficiency of the community of beneficial insects. This management obviously includes the maintenance of a vegetation cover, and very especially, the absence of application of any type of pesticides (organic and synthetic), so that in this the control of pests is due exclusively to the entomophagous action itself. As expected, in both types of management, orchards must exhibit a higher arthropod abundance that conventionally managed orchards $[1,9,14]$.

In view of the relative variability of agricultural conditions and practices among the different types of management that affect olive cultivation at present, our objective is to highlight the differences in terms of beneficial entomocenosis, which constitute the main natural element of pest control, and represents an clear indicator of the degree of sustainability of this agroecosystem.

\section{Material and Methods}

\section{Description of the study area}

The study was carried out in olive groves in the province of Jaén (Andalusia, southern Spain) during the spring and summer of 2017. According to the objectives of the study, three olive groves relatively close to each other were selected (Figure 1), each of them subject to the Conventional (C), Ecological (ECO), and Integrated Pest Management (IPM). The main characteristics of the three types of management are described below, as well as the pesticide application regime (Table 1).

Figure 1: Location map of the study area and the different olive groves considered in the study. 1. Conventional; Management. 2. Integrated Management, 3. Ecological Management.

Table 1: Characterization of the different types of olive Management according to the chemical treatments applied to different pests / pathogens (period 2007- 2017; Spanish AgriculturalMinistry \& Spanish Committee of Ecological Agriculture).

\begin{tabular}{|c|c|c|c|c|}
\hline & & \multicolumn{3}{|c|}{ Management } \\
\hline & & Conventional & IPM & Ecological \\
\hline Pest/Pathogen & Active Principles & $\begin{array}{l}\text { Volume-Weight (avg/ Ha } \\
\text { \& year) }\end{array}$ & $\begin{array}{l}\text { Volume-Weight (avg/ Ha } \\
\text { \& year) }\end{array}$ & $\begin{array}{c}\text { Volume-Weight (avg/ Ha } \\
\text { \& year) }\end{array}$ \\
\hline Herb Vegetation & $\begin{array}{c}\text { Glyphosate }(20 \%)+ \\
\text { Oxifluorfen }(3 \%)\end{array}$ & $\begin{array}{c}0,3 \mathrm{~L} / \mathrm{Ha} \\
4 \mathrm{~L} / \mathrm{Ha}\end{array}$ & --- & --- \\
\hline $\begin{array}{l}\text { Fusicladiumoleagineum } \\
\text { Colletotrichum gloesporides } \\
\text { Pseudomonas savastanoi }\end{array}$ & $\begin{array}{l}\text { Copper oxychloride }(20 \%) \\
+\quad \text { Propineb }(15 \%)\end{array}$ & 0,8 Kg / Ha & 0,8 Kg / Ha & --- \\
\hline Aceria oleae & S (80\%) & $1,4 \mathrm{Kg} / \mathrm{Ha}$ & 0,75 Kg/Ha & --- \\
\hline Prays oleae & Dimethoate $40 \%$ & 0,9 L / Ha & 0,3 L /Ha & --- \\
\hline Euzophera pinguis & Chlorpyrifos $48 \%$ & $1,5 \mathrm{~L} / \mathrm{Ha}$ & $0,75 \mathrm{~L} / \mathrm{Ha}$ & --- \\
\hline Phloeotribus scarabaeoides & Dimethoate $40 \%$ & 0,9 L / Ha & $0,45 \mathrm{~L} / \mathrm{Ha}$ & --- \\
\hline Bactrocera oleae & Dimethoate $40 \%$ & 1,8 L / Ha & 0,9 L / Ha & --- \\
\hline
\end{tabular}

Olive grove Conventional Management (CM): Of coordinates $37^{\circ} 36^{\prime} 18.20^{\prime \prime} \mathrm{N} 3^{\circ} 28^{\prime} 33.59^{\prime \prime} \mathrm{W}$. The olive trees are of the picual variety, of 20-30 years of age and are planted at a density of 100 olive trees / hectare. Regularly, preemergence herbicides are applied in order to keep the olive grove free from any adventitious plant. The control of pests is carried out by commercial organophosphorus insecticides, applied regularly, for which Dimetoate 40\% (400 g / l) (BASF) is used, at a concentration of $0.1 \%$ (100 cc / hl), applied during the spring and autumn.

Olive grove Integrated pest Management (IPM): Of

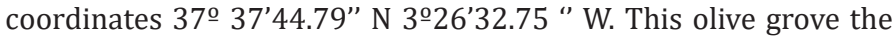
olive trees are of the picual variety, of age and density of plantation 
similar to the Conventional olive grove. In this olive grove the growth of a vegetation cover located in a band of approximately $2.5 \mathrm{~m}$, in the central area of the interline, and which is periodically controlled by the use of a brushcutter, is encouraged. This objective is to reduce water competition with olive trees from the month of April, when this resource is scarce. Pest control is carried out through the application of commercial organophosphorus insecticides. Among the species that form this cover, the following stand out: Lolium rigidum Gaudin, Senecio vulgaris Linneo, Poa annua Linneo, Silene colorata Poiret, Diplotaxis virgata Candolle, Muscari neglectum Gussone, Sinapis alba Linneo, Equisetum arvense Linneo, Bromus madritensis Linneo, Convolvulus althaeoides Linneo, Phalaris minor Retzius, Daucus carota Linneo, Cirsium arvense Scopoli and Anacyclus clavatus Persoon.

Olive grove Ecological Management (EM). The olive grove has the coordinates $37^{\circ} 37^{\prime} 24.38^{\prime \prime} \mathrm{N} 3^{\circ} 29^{\prime} 51.22^{\prime \prime} \mathrm{W}$. It is an olive grove with trees of about 18 years of age; there is no synthetic chemical product applied, which includes pesticides and fertilizers. As in the case of the IPM olive grove, this allows the development of an adventitious herbaceous plant cover during the fall, winter and spring. Pest control depends almost exclusively on the entomophagous activity of natural enemies. The species that form this cover basically coincide with those described for the IPM olive grove, although in this case it is worth mentioning the presence of characteristic vegetation of the Mediterranean forest in the adjoining areas of the olive grove, in which Quercus ilex, Rosmarinus officinalis and Stipa tenacissima stand out, among others.

\section{Experimental set up}

The study was carried out during the oviposition period of the phytophagic generation of Prays oleae (Lep.; Praydidae), at which time intense activity takes place on the part of the natural enemies [15], which takes place mainly during the month of May, in the south of Spain.

In each of the selected olive groves corresponding to the different types of management (Conventional, Integrated Pest Control and Ecological), 6 plots of dimensions $30 \times 30$ meters (900) were established, each of them containing 9 olive trees. The minimum distance between the plots has been approximately 150 m.

The monitoring of the community of natural enemies has been carried out through a passive sampling method, based on the use of yellow chromatic sticky traps. This kind of sampling, that relies on the movement of the arthropods towards the traps [16] has shown excellent results, and is appropriate for replication $[8,17,18]$.

Two yellow sticky traps, of dimensions $20 \mathrm{~cm}$ x $40 \mathrm{~cm}$, were installed in each of the olive trees of the plots, at an approximate height of $1.50 \mathrm{~m}$ from the ground, in the NE sector, in order to adapt the samplings to the microclimatic preferences of the natural enemies, and separated $50 \mathrm{~cm}$ from each other, and at a height of $1.70 \mathrm{~m}$ from the ground.

Since the beginning of May 2017, 4 sampling intervals of 5 days have been considered: 5-10 May, 10-15 May, 15-20 May, and 20-
25 May. The total number of traps for each type of handling has been 106 in each sampling interval. In each sampling interval, and in order to avoid the effects of pseudo-replication [19], a plot was randomly selected for each type of management, from which the traps were removed for study (18 traps / sampling). and type of management). Obviously, at the end of each sampling interval, all the traps were renewed. Once in the laboratory, the traps were temporarily stored in a cold chamber ( $\left.4^{\circ} \mathrm{C}\right)$, and then examined by means of a binocular magnifying glass for the taxonomic determination of the captured specimens and the quantification of the catches for each species.

Among the group of species captured in the chromatic traps, for this study those that meet at least two of the following criteria have been considered:

a. Entomophage relevance in the olive grove. Species associated to at least one phytophagous pest of the olive grove [15,20-23].

b. Ecological adaptability. Entomophagous relatively polyphagous, present in a wide range of ecosystems, associated to diverse phytophages, of agricultural or forestry importance.

c. Susceptibility to pesticides. Natural enemies, reported as highly susceptible to pesticides, have been selected.

\section{Statistical analysis}

Statistical analysis was carried out using statistical package Statgraphics Centurion XVII (2016). The normality of the distributions has been verified by the Chi-square and KolmogorovSmirnov tests (K-S), with the correction of Liliefors. The Levene test has been applied to evaluate the homogeneity of the variances for a variable calculated for two or more groups. The Mann-Whitney U test (M-W) was applied for comparison between two groups.

\section{Results and Discussion}

The application of the criteria to the captures of natural enemies in the chromatic traps have allowed to select 11 species of predators and 7 parasitoids. Of these, a total of 4345 individuals have been identified, and values of relative abundance in the olive groves subject to the different management are presented in Figure $1 \& 2$.

\section{Predators}

The most abundant species of insect predator (84\%) was Aeolothrips intermedius Bagnall (Thys., Aeolothripidae). This insect is present in a wide range of cultures [24, 25], feeding mainly on several tysanopteran species, as well as to pests' mites [24]. In the olive grove, they feed on Liothrips oleae Costa (Thys., Phlaeotripidae) [15], and specially on the parasitic mites Aceria oleae Nalepa and Oxycenus maxelli Keifer (Acari, Eriophyidae).

The neuropteroids reached a proportion of 5,5\% of the total number of individual captured. Among them, the most abundant was Chrysoperla agilis (Neur., Chrysopidae) and the snakefly Harraphidia laufferi (Navás, 1915) (Raph., Raphidiidae). The 
chrysopids, referred to as Chrysoperla carnea (Stephens, 1836) sensu lato, the so-called "common green lacewings" belong to the best tested beneficial insects regarding their pesticide susceptibility [26]. The taxonomic status of the species in question has been changing, and instead of a particular species, a complex of sibling or cryptic species, the Chrysoperla carnea complex, or carnea-group $[27,28]$, should be taken into account. The existence of various sibling species has been assumed: 1) Ch. affinis former Ch. kolthoffi [2,27] Chrysoperla lucasina (Lacroix, 1912) [3,28] Chrysoperla carnea sensu stricto [27] or Chrysoperla pallida [4,29] Chrysoperla agilis sp. nov. [30]. In the south of Spain, the presence of these cryptic species in Andalusian olive groves, has been reported, of which Ch. agilis was dominant (>90\%), [31], which agree with this study. In the olive groves, the carnea-complex are polyphagous and effective predators in the natural control of the olive moth Prays oleae [15, 31], hemipterans psyllids, Euphyllura olivina, and scales species of families Coccidae and Diaspididae.

The snakefly Harraphidia laufferi (Raph., Raphidiidae) is a predator quite common in the olive groves [32], feedind on bark beetles' larvae of Phloeotribus scarabaeoides Bern. (Col., Scolytinae) [33] at the larval stage. Larval stage develops on the olive bark, and they must be relevant natural enemies of the olive borer, Euzophera pinguis (Lep., Pyralidae) [32]. At the adult stage, on the olive groves, raphidiopteran feed on several sap suckers of the herbaceous cover, mainly aphids (Hem., Aphidiidae) as well as on nymphs of olive psyllid, Euphyllura olivina [32].

Among the predators, the hemipteran species reached a proportion of ca. $8 \%$, and among them, three species of anthocorids have been collected. Anthocorids are commonly cited in olive orchards [21, 34, 35]. The species collected in this study were Anthocoris nemoralis F., the pirate bug, Orius laevigatus (Fieber), and Temnostethus gracilis (Horváth). They are associated to a wide range of crops and consume a wide variety of pests including mites, thrips, aphids, small caterpillars, psyllids and whiteflies. In the olive grove, they prey on psyllids, Euphyllura olivina (Hem, Psyllidae) spider mites [21], thrips, Liothrips oleae [15, 34] and small caterpillars, Prays oleae [15].

Ladybirds were also among the predators captured, representing a proportion of $2,3 \%$ from the total. The collected species were Sthethorus punctillum Weise, Adalia bipunctata L. and Coccinella septempunctata L. Former species, known as the spider mite destroyer lady beetle, is an effective agent in IPM programs, feeding on the red mite, Tetranychus urticae [36].It occurs in tree plantations, gardens and crop fields where it mainly attacks two-spotted spider mite (Tetranychus urticae Koch. Ladybirds C. septempunctata are predators of the several major scales pests, such as the black scale, Saissetia oleae Oliv. (Hem., Coccidae), the olive scale, Parlatoria oleae Colvée, the oystershell scale, Lepidosaphes ulmi L. [15], and the oleander scale, Aspidiotus nerii Bouché (Diaspididae) [21].

Predators showing the lowest abundance were the syrphids $(0,9$ $\%)$, among them, the species: Syrphus ribesii L. and Sphaerophoria scripta L. (Syrphidae) have been collected.In the olive groves, the hoverflies larvae are important predators of the olive psyllid, Euphyllura olivina [21,24].

\section{Parasitoids}

Graph 2 shows the frequency of capture of the different parasitoid species. These include the presence of eulopids (Hym, Eulophidae), Which presented the highest capture rate (67\%), among them Pnigalio mediterraneus (Ferrierre \& Delucchi, 1957) and Tetrastichus cesirae (Russo, 1938), were the most abundant. Pnigalio mediterraneus is a generalized ectoparasitoid species that is very often associated with the olive fly, Bactrocera oleae in Mediterranean countries [37,38].

The braconids reached 2,3\% of the total captures, having recorded Psyttalia concolor (Szépligeti) and Dinocampus coccinellae (Schrank 1802). The former has been cited in many areas of the Mediterranean basin [39-41], which is a larval endoparasitoid, mainly found late autumn. Dinocampus coccinellae is a parasitoid that attacks several species of coccinellids, which makes it a potential threat to agriculture [42].

Ageniaspis fuscicollis (Dalman, 1820) (Hym., Encyrtidae) is an important parasitoid, associated with the olive moth, Prays oleae (Bernard), being the most abundant in practically all of the olive producing regions [43]. This species is relatively polyphagous, so it has been used for the control of several species of microlepidopteran, as for example being introduced for the control the apple ermine moth, Yponomeuta malinellus (Borkh) in North America [44].

Finally, a $3,6 \%$ of the abundance corresponded to the Ichneumonids, between which Itoplectis alternans (Grav.) and Angitia armillata Gravenhorst stand out, both parasitoids are of important action on the larvae populations of the flower-feeding generation of the olive moth, Prays oleae [21].

\section{Analysis of the influence of agricultural management on the abundance of beneficial insects}

As shown in Figure $2 \& 3$, most of the species of natural enemies (15 of 18 species) have higher values in the olive grove with Ecological Management. The application of the statistical tests to the species selected due to their highest capture value ( 6 predators and 3 parasitoids), show, in effect, a higher density in the Ecological Management, statistically significant in all cases (Figure 4). Among these 9 species, only 4 of them (the parasitoids P. mediterraneus, T. cesirae, A. fuscicollis, and the predator A. nemoralis), showed similar abundance values in both Integrated an Ecological Management.

When considering the elements that differentiate the three types of management (presence / absence of cover of herbaceous plants in the area of cultivation, and presence / absence of application of pesticides), the results obtained allow us to establish the following groups in the natural enemies, depending on their susceptibility to both differential factors:

A. The absence of vegetal cover seems to be a very negative factor, affecting the parasitoids P. mediterraneus, T. cesirae and A. fuscicollis, and the predator A. nemoralis, so their presence shows 
the minimum values in conventional management, there were no significant differences between the two management models that include vegetation coverage (IPM and Ecological).

B. The use of pesticides seems to be a factor that by itself affects very negatively to species such as A. intermedius and S. punctillum, whose maximum values of abundance were recorded only in the Ecological Management. On these species, the presence/ absence of vegetal cover does not seem to affect very negatively, as a results of the absence of statistical differences between Conventional and Integrated pest management.
C. The combination of both factors (pesticides and vegetal cover) seems to exert an influence jointly, which affects the abundance of some beneficial species such as A. decempunctata, $\mathrm{Ch}$. agilis and $\mathrm{H}$. laufferi. They therefore showed maximum values in the Ecological management, intermediate values in the IPM, and mínimum population values in the Conventional Management. Among these species, A. decempunctata and H. laufferi seems to be the most susceptible to pesticides, since they are completely absent in the Conventional management, which agree with previous studies [45].

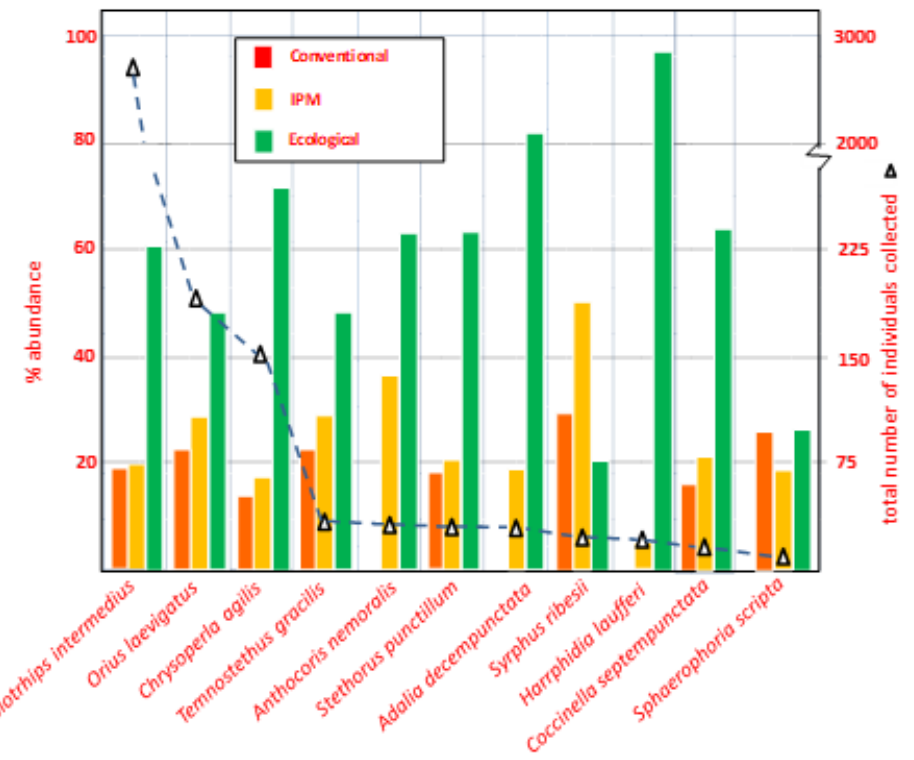

Figure 2: General index of relative abundance of the predator species captured, and percentages corresponding to the three agricultural management considered (Conventional management, Integrated Pest Management and Ecological Management).

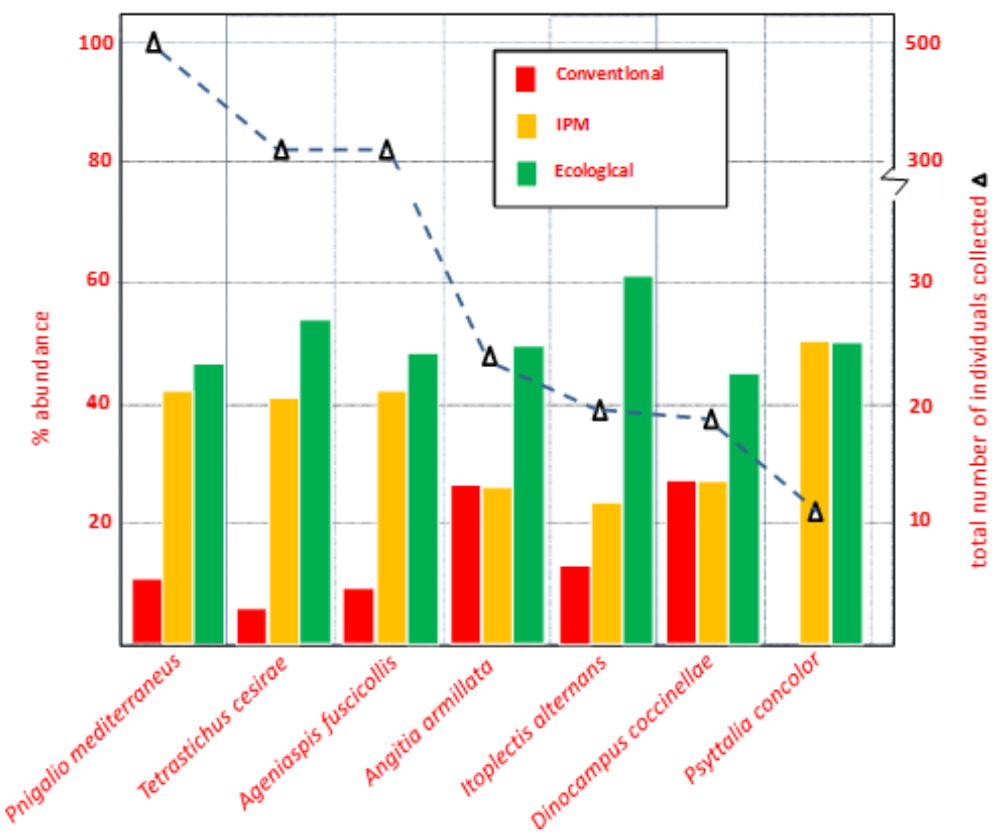

Figure 3: Relative abundance of the parasitoid species captured, and percentages of abundance corresponding to the different agricultural management (Conventional Management, Integrated Pest Management and Ecological Management). 

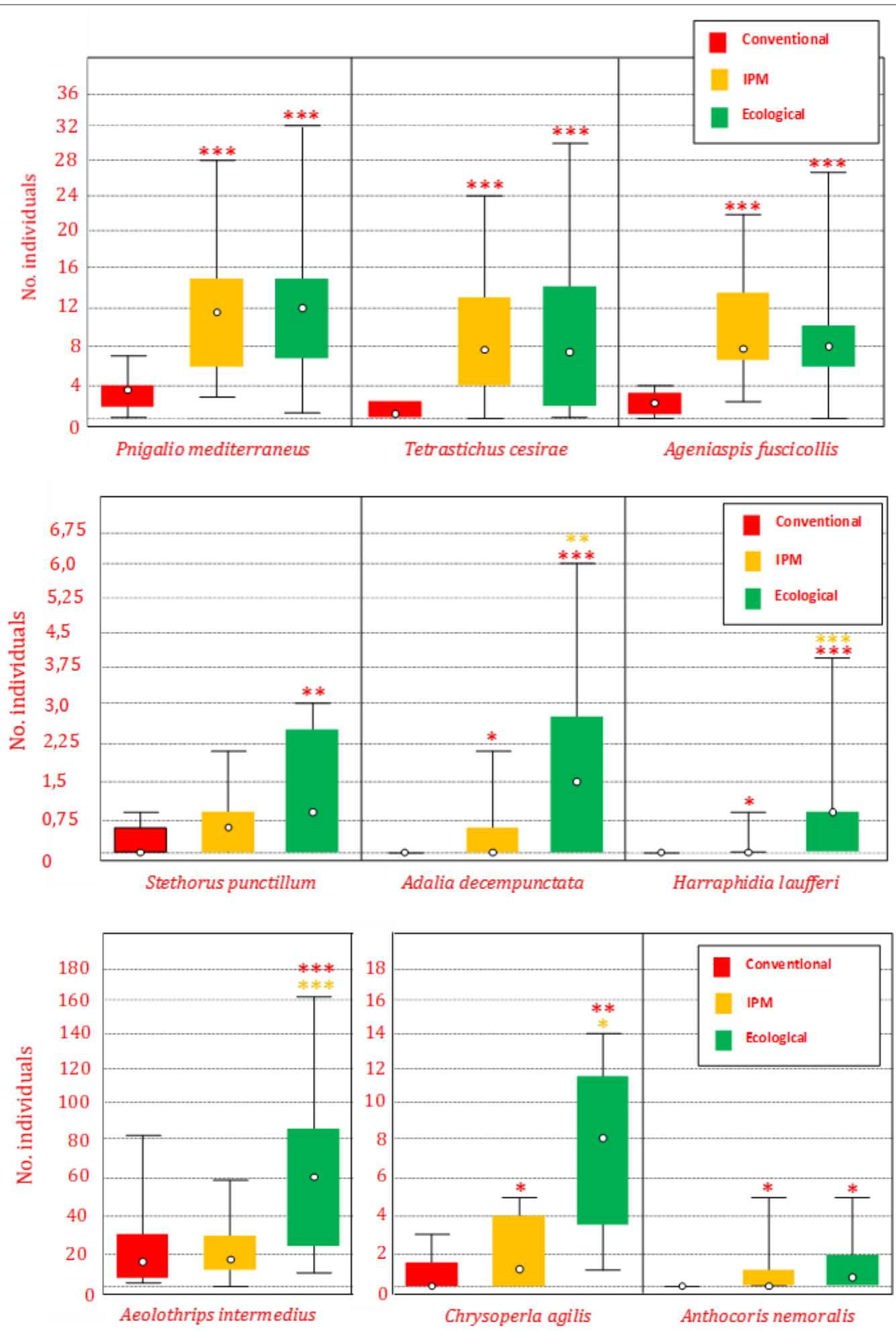

Figure 4: Abundance of the main species of predators and parasitoids in the different types of agricultural management tested. The statistical differences (Mann-Whitney test) are indicated by asterisks in red (compared to conventional handling) and orange (with respect to IPM management) the level of significance $\left.\left(^{*}\right): p<0.05 ;{ }^{* *}\right): p<0.01 ;\left(^{* * *}\right) p<0.001$.

The implantation of herbaceous plant covers exerts multiple beneficial effects, not only by limiting erosion and soil loss [2] but also by promoting animal biodiversity, which is a biological obviousness, and has thus frequently been reported $[1,4,7]$. Reduces dependence on pesticides and provides a much more sustainable agrosystem than Integrated Management, and especially conventional management. Together with the above, the lower dependence on pesticides provides optimal conditions for the stimulation of biodiversity and reinforces the chances of survival of beneficial species in general, and in particular those that are extremely susceptible, as is the case of coccinellids and the raphidiopteran [45]. It is important, however, to consider the 
effect of the application regime of pesticides, so that integrated management, as seen in the results of this study, represents a less aggressive situation, and intermediate in terms of biodiversity, in relation to the Conventional and Ecological management.

\section{Conclusion}

This study has allowed to determine the existence of notable differences between the conventional, IPM and Ecological management. the lowest diversity and abundance indexes of the beneficial fauna are present in the olive groves with conventional management. An opposite situation is observed in the ecological olive grove, while in the olive grove integrated management objective, intermediate values of diversity and abundance are presented.

The presence / absence of herbaceous plant cover and pesticide applications constitute the differential factors responsible for the differences in diversity and abundance of the beneficial fauna among the three types of management considered. The combination of both factors (applications of pesticides and plant cover) exert a joint influence, which affects the presence and / or abundance of species of Chrysopidae, Coccinellidae and Raphidiidae, families where the main natural enemies of pests of the olive pest, are included.

\section{Acknowledgments}

The authors would like to thank A. Gómez Roa, E. M, Guzmán García and F. Millán, for his kindness in lending us the ideal growing areas to this study. Appreciation is also expressed to V. Gómez Roa, for her help in improving the English version. Thanks, are also due to the invaluable help by F. J. García Marín and J. M. Barragán Barrera in the field and laboratory work.

\section{References}

1. Picchi MS, Marchi S, Albertini A, Petacchi R (2017) Organic management of olive orchards increases the predation rate of overwintering pupae of Bactrocera oleae (Diptera: Tephritidae). Biological Control 108: 9-15.

2. Pastor M, Castro J, Humanes M, Muñoz J (2001) Sistemas de cultivo con cubiertas en olivar de Andalucía (II). Vida Rural 126: 46-51.

3. Rodríguez E, González B, Campos M (2012) Natural enemies associated with cereal cover crops in olive groves. Bulletin of Insectology 65(1): 43-49.

4. Porcel M, Cotes B, Castro J, Campos M (2017) The effect of resident vegetation cover on abundance and diversity of green lacewings (Neuroptera: Chrysopidae) on olive trees. Journal of Pest Science 90(1): 195-206.

5. Corrales N, Campos M (2004) Populations, longevity, mortality and fecundity of Chrysoperla carnea (Neuroptera, Chrysopidae) from oliveorchards with different agricultural management systems. Chemosphere 57(11): 1613-1619.

6. Laureto L, Cianciaruso M, Samia D (2015) Functional diversity: An overview of its history and applicability. Natureza e Conservacao. Associação Brasileira de Ciência Ecológica e Conservação 13(2): 112116.

7. Gómez JA, Campos M, Guzmán G, Castillo Llanque F, Vanwalleghem T, et al. (2018). Soil erosion control, plant diversity, and arthropod communities under heterogeneous cover crops in an olive orchard. Environmental Science and Pollution Research 25(2): 977-989.
8. Dimitrova A, Livieratos I, Gkisakis V (2018) Trapping methodologies for functional canopy arthropod diversity in olive agroecosystem. 2nd Mediterranean Forum Research and Innovation as Tools for Sustainable Agriculture, Food \& Nutrition Security, Italy.

9. Gkisakis VD, Bàrberi P, Kabourakis EM (2018) Olive canopy arthropods under organic, integrated, and conventional management. The effect of farming practices, climate and landscape, Agroecology and Sustainable Food Systems 42(8): 843-858.

10. Kenmore PE, Eeong KL, Putter CA (1984) Political, social and perceptual aspects of integrated pest management programmes. Malaysian Plant Protection Society 47-66.

11. Siddiqui AA, Siddiqui M, Knox O (2012) Assessing the impact of Integrated Pest Management Farmer Field Schools (IPM-FFSs) on acquisition of farmers' knowledge regarding use of pesticide, nutrient management and confidence in decision making process. Pakistan Journal of Life and Social Sciences10(2): 150-155.

12. Ehi Eromosele CO, Nwinyi OC, Ajani OO (2013) Integrated pest management. In Weed and Pest Control-Conventional and New Challenges. InTech.

13. Benhadi Marín J, Pereira JA, Sousa JP, Santos SA (2018) Influence of landscape features and management practices in olive groves for optimized pest control. XI European Congress of Entomology, Italy.

14. Santos SA, Cabanas JE, Pereira JA (2007) Abundance and diversity of soil arthropods in olive grove ecosystem (Portugal): Effect of pitfall trap type. European Journal of Soil Biology, 43(2): 77-83.

15. Arambourg Y (1986) Traité d'entomologie oleicole. Consejo Oleícola Internacional. Gráficas Marte, Madrid, Spain.

16. Gullan PJ, Cranston PS (2010) The insect an outline of entomology. Fourth edition, Wiley- blackwell, Malden, USA.

17. Delvare G, Aberlenc HP, Adis J, Springate ND, Stork NE, et al. (1997). A review of methods for sampling arthropods in tree canopies. Canopy arthropods 27: 52 .

18. Young M (2007) Insects in Flight. Insect Sampling in Forest Ecosystems pp. 116-145.

19. Hurlbert SH (1984) Pseudoreplication and the design of ecological field experiments. Ecological monographs 54 (2): 187-211.

20. Hodkinson ID, Hughes MK (1993) La fitofagia en los insectos. Oikos-tau, Barcelona, Spain.

21. De Andrés Cantero F (2001) Enfermedades y Plagas del olivo. Riquelme y Vargas Ediciones, SL Jaén, Jaén, Spáin (4): 646.

22. Guerrero García A (2003) Nueva Olivicultura. Ed. Mundi-Prensa, Madrid, Spain, (5): 225.

23. Vossen PM, Zalom FG (2009) Intraspecific larval competition in the olive fruit fly (Diptera: Tephritidae). Environmental Entomology 38(5): 14001410.

24. De Liñán Vicente C (1998) Entomología Agroforestal, Ed. Agrotécnicas, SL Madrid, Madrid, Spain pp. 1294.

25. Nikolova I, Georgieva N, Tahsin N (2015) Toxicity of neem and pyrethrum products applied alone and in combination with different organic products to some predators and their population density. Romanian Agricultural Research 32(32): 291-301.

26. Bozsik A (2008) Pesticide testing on adults of the Chrysoperla carneacomplex (neuroptera: Chrysopidae) and the sibling species problem in the toxicology of common green lacewings, 2008 Proceedings of the Thenth International Symposium on Neuropterology. Maribor, Slovenia pp. 113-120.

27. Thierry D, Cloupeau R, Jarry M, Canard M (1998) Discrimination of the West-Palaearctic Chrysoperla Steinmann species of the carnea Stephens group by means of claw morphology (Neuroptera, Chrysopidae). Acta Zoologica Fennica 209: 255-262. 
28. Henry CS, Brooks SJ, Thierry D, Duelli P, Johnson JB (2001) The common green lacewing (Chrysoperla carnea s. lat.) and the sibling species problema. Lacewings in the crop environment. Cambridge University Press. Cambridge, UK p. 29-42.

29. Henry CS, Brooks SJ, Duelli P, Johnson JB (2002) Discovering the true Chrysoperla carnea (Insecta: Neuroptera: Chrysopidae) using song analysis, morphology and ecology". Annals of the Entomological Society of America 95(2): 172-191.

30. Henry CS, Brooks SJ, Duelli P, Johnson JB (2003) A lacewing with the wanderlust: The European song species "Maltese" Chrysoperla agilis, sp. N. of the carnea group of Chrysoperla (Neur.: Chrysopidae). Systematic Entomology 28: 131-149.

31. Bozsik A, González Ruíz R, Hurtado Lara B (2009) Distribution of the Chrysoperla carnea complex in southern Spain (Neuroptera: Chrysopidae). Analele Universității din Oradea. Fascicula: Protecția mediului 14: 71-78.

32. Rozas L, González Ruiz R (2013) Primeros datos sobre la influencia de las cubiertas vegetales en la presencia de Raphidioptera (Insecta: Neuropteroidea) en olivares de Jaén. XVI Scientific-Technical Symposium on Olive Oil. Fundación del Olivar. Spain.

33. González Ruiz R (1989) Estudio Bioecológico de Phloeotribus scarabaeoides (Col.: Scolytidae) en la provincia de Granada. Tesis Doctoral, Universidad de Granada, Granada pp. 450.

34. Bejarano Alcázar JD, Rodríguez Jurado JM, Durán Álvaro M, Ruiz Torres MJ, Herrera Mármol H (2011) Unidad Didáctica 5. Control de enfermedades y plagas en producción integrada del olivar. Producción Integrada de Olivar, Instituto de Investigación y Formación Agraria y Pesquera. Junta de Andalucía, Spain, p. 55-90.

35. Pascual S, Cobos G, Seris E, González Nuñez M (2014) Spinosad bait sprays against the olive fruit fly (Bactrocera oleae (Rossi)): effect on the canopy non-target arthropod fauna. International Journal of Pest Management 60(4): 258-268.

36. Ragkou VS, Athanassiou CG, Kavallieratos NG, Tomanovi Ž (2004) Daily consumption and predation rate of different Stethorus punctillum instars feeding on Tetranychus urticae. Phytoparasitica 32(2): 154-159.

37. El Heneidy AH, Omar AH, El Sherif H, El Khawas MA (2001) Survey and seasonal abundance of the parasitoids of the olive fruit fly, Bactrocera (Dacus) oleae Gmel. (Diptera: Trypetidae) in Egypt. Arab J Plant Prot 19 (2): 80-85.

38. Neuenschwander P, Bigler F, Delucchi V, Michelakis S (1983) Natural enemies of preimaginal stages of Dacus oleae Gmel. (Dipt., Tephritidae) in Western Crete. I. Bionomics and phonologies. Boll Lab Entomol Agrar Filippo Silvestri 40: 3-32.

39. Raspi A, Canovai R, Antonelli R (1996) Andamento dell'infestazione di Bactrocera oleae (Gmelin) in oliveti del Parco regionale della Maremma. Frustula entomologica 19: 189-198.

40. Raspi A, Loni A, Canovai R, Canale A (2007) Entomophages of olive pests in Corsica, coastal Tuscany and Islands of Tuscan archipelago. Frustula entomologica 30: 187-194.

41. Raspi A, Canale A, Loni A, Bagnoli B (2019) Osservazioni sul comportamento di Psyttalia concolor nei confronti di Bactrocera oleae. Acta Italus Hortus 10: 198-201.

42. Bruce A (2011) Parasitoid wasp threatens Scottish Seven Spot ladybird. Microscopy UK.

43. Villa M, Santos SA, Pereira JA (2017) Análisis de supervivencia de Ageniaspis fuscicollis (Dalman), parasitoide de la polilla del olivo. X Congreso Nacional de Entomología Aplicada y XVI Jornadas Científicas de la SEA. Logroño, Spain.

44. Cossentine JE, Kuhlmann U (2000) Status of Ageniaspis fuscicollis (Hymenoptera: Encrytidae), an introduced parasitoid of the apple ermine moth (Lepidoptera: Yponomeutidae. The Canadian Entomologist 132 (5): 685-689.

45. Gómez Guzmán JA, García Marín FJ, Sáinz Pérez M, González Ruiz R (2017) Behavioural Resistance in Insects: Its Potential Use as Bio Indicator of Organic Agriculture. IOP Conference Series: Earth and Environmental Science 95 (4): 1-10. 